\title{
An Empirical Study of Declining Lead Times: Potential Ramifications on the Performance of Early Market Entrants
}

\author{
Michael J. Poletti, Brian T. Engelland, and Howard G. Ling
}

This study examines innovation lead time, the construct believed to be the key determinant of launch order strategic value. Anecdotal evidence has suggested that innovation lead times are continuing to decrease as the result of new product development acceleration strategies. However, broad scale empirical evidence regarding product launches since 1984 has not been forthcoming. This study fills the void by comparing lead times for first movers and second movers across a 20-year time span, ending in 2004. Results confirm that first-mover lead times have continued to decrease significantly, whereas second-mover lead times have decreased marginally.

Innovation is a vital ingredient in the survival and success of firms. Innovation in new products and services enables the development of durable first-mover advantage by supporting the creation of isolating mechanisms such as proprietary technology, switching cost hurdles, and resource preemption that slow down competitive reaction and increase innovation lead time (Suarez and Lanzolla 2005, 2007). As a result, earlier entrants can enjoy extended periods of prosperity and profitability before later entrants come into the market (Short and Payne 2008; Suarez and Lanzolla 2005, 2007, 2008).

However, first-mover advantage becomes less potent when the first mover fails to have enough time to establish effective barriers to competitive entry. Innovative followers can reduce the lead time enjoyed by first movers by using technological advances to speed up the pace of change and facilitate transference of knowledge (Agarwal and Gort 2001; Langerak and Hultink 2005). In this way, fast followers can respond more quickly to pioneering action, giving the earlier mover less time to establish consumer preference, dominate distribution channels, and create other structural barriers to competition.

Innovation designed to speed up response to pioneering innovation has been a powerful force from the industrial revolution forward. Indeed, in a study of 46 new product innovations introduced from 1887 to 1986, the average first-mover lead time decreased from almost 33 years at the turn of the century to 3.4 years by the $1980 \mathrm{~s}$ (Agarwal and Gort 2001). A follow-up study involving 95 new products also introduced prior to 1984 confirmed that first-mover lead times had declined, especially in the later periods (Vakratsas, Rao, and Kalyanaram 2003). However, these studies were based on pre-1985 data, and little empirical work has been completed since then to extend these results into the twenty-first century. Marketing strategists are left with two unanswered questions: Are innovation lead times still decreasing? Have improvements in product development systems reached the point of diminishing returns?

The answers to these two questions are important to marketing strategists concerned with the performance-related potential of new product launch as a business development strategy. The benefits that first movers create are realized only to the 
extent that temporal strategic barriers can be activated and maintained (Patterson 1993). If lead times are still decreasing significantly, then temporal barriers must not be as robust as previously established and calls into question the relevancy and impact of the pioneering strategy to grow the business. Under these changing environmental conditions, a rapid follower strategy may be just as effective.

But what happens to the second mover when a third mover enters the market? Does the second mover enjoy stability in lead time so as to establish its second-mover position and reap the benefits of a stable market? Is second mover lead time declining as quickly as first-mover lead time? To date, there have been no empirical studies of second-mover lead time, and consequently, it is difficult to determine whether the "fastsecond" strategic approach is gaining in viability.

Accordingly, this paper has two objectives. First, we build on the work of Agarwal and Gort (2001) and Vakratsas, Rao, and Kalyanaram (2003) in understanding what is happening to innovation lead times by evaluating post-1984 data. Second, we examine innovation lead times not only for first movers but for second movers as well. To our knowledge, this is the first comprehensive study of innovation lead times that incorporates both. By studying both categories, a more comprehensive understanding of the lead time phenomenon is achieved. We believe that this is especially important for followers' timing of response, an issue that has only recently gained the attention of marketing researchers (Kuester, Homburg, and Robertson 1999; Vakratsas, Rao, and Kalyanaram 2003).

This paper briefly discusses the advantages conferred to early movers and the importance of lead time in determining the viability of launch order strategy. Then, hypotheses addressing lead time are advanced and tested. Finally, conclusions are drawn and suggestions are made on how marketing strategists might utilize changes in lead time to their advantage.

\section{BACKGROUND}

A firm that is first to enter the market with a specific product or service is the pioneer or first mover (Lieberman and Montgomery 1988). The next competitor to enter with a substantially similar offering is referred to as the second mover, and subsequent market entrants are called third movers or fourth movers, and so on, depending on their order of launch. For decades, it has been assumed that first movers initially enjoy short-term benefits as they operate as a monopoly before later entrants arrive. Second movers also enjoy a period of reduced competition until a third mover enters the market. These periods of reduced competition are called innovation lead time and are defined as the elapsed time between the date of prior product entry and the date of competitive imitation (Lee et al. 2000). Innovation lead time is sometimes confused with time to market, which is defined as the elapsed time from a product being conceived until it is made available for sale (Kahn 2004). The management process involved in conceiving 
a product to respond to a competitive entry can involve days, weeks, or years. Consequently, innovation lead time can be considerably longer than time to market.

\section{First-Mover Advantage}

Given the weight of evidence provided in economic, management, and marketing literature, being first to market (pioneering) would seem to be an excellent strategy for a firm to employ (Alpert 1987; Buzzell, Gale, and Sultan 1975; Carpenter and Nakamoto 1990; Conrad 1983; Robinson and Min 2002). The literature suggests that a negative relationship exists between order of market entry and market share (Kalyanaram, Robinson, and Urban 1995; Vakratsas, Rao, and Kalyanaram 2003), and further research indicates that increased lead times can enhance first-mover market share advantages (Huff and Robinson 1994; Vakratsas, Rao, and Kalyanaram 2003). Consequently, first movers should achieve higher market share than followers.

But a tighter look at the literature reveals that early movers (first and second movers) create for themselves the potential for garnering large benefits only to the extent that temporal strategic barriers can be activated and maintained. Entry barriers such as proprietary knowledge and patent protection, which initially allow the pioneer to operate as a pseudo-monopoly, afford greater value than barriers that may take time to activate, even if they have the potential to provide longer-term benefits. The effectiveness of entry barriers in deterring competitor entry and the length of time first movers are able to earn monopoly-like profits depend largely on the first mover's ability to impede competitive reaction (D'Aveni 1994; Nelson and Winter 1982). Consequently, early movers will attempt to engage in product and market innovation strategies that increase structural barriers between themselves and subsequent followers. The higher the barriers, the longer the early mover lead time becomes; the lower the barriers, the shorter the lead time.

Innovation lead time provides a window of opportunity for the early mover to solidify potentially sustainable advantages that can be broadly characterized as either consumer-based (Huff and Robinson 1994) or producer-based advantages. Consumerbased advantages are discussed first.

Carpenter and Nakamoto (1989) explained first-mover advantage in terms of the role of learning in consumer preference formation and suggested that the process by which consumers learn about brands plays an important part in creating first-mover advantage. The first mover may be able to influence how product attributes are valued, define the ideal attribute combination, and ultimately influence consumers' preferences to the first-mover's benefit (Carpenter and Nakamoto 1989). Further, it is possible that the first mover can define a product category and thus become the "prototype" against which all later entrants are judged (Alpert 1987; Engelland and Alford 2000). First movers can also profitably use this lead time to establish an even stronger brand name (Schmalensee 1982) and preempt later entrants with important line extensions (Robinson 1988). 
In addition to these consumer-based advantages, there are believed to be many producer-based advantages. The producer-based advantages include economies of scale, asymmetric information about product quality and riskaverse buyers, experience effects, and reputational effects (Lieberman and Montgomery 1988; Robinson 1988; Suarez and Lanzolla 2007). Early movers can lengthen innovation lead time through the establishment of technological leadership, preemption of scarce resources such as raw materials and distribution channels, and by building in buyer switching costs (Lieberman and Montgomery 1988). All of these producer-based advantages serve to build strong entry barriers that increase the innovation lead time between early movers and the response of followers (Suarez and Lanzolla 2007).

Both consumer-based and producer-based advantages allow the early mover to benefit by initially operating as a monopolist or semimonopolist while establishing market position and learning curve economies (Von Hippel 1984). These may allow it to retain a dominant market share and higher profits than subsequent entrants would earn. For instance, when Software Arts introduced VisiCalc in May 1979, the product was received as the first truly user-friendly spreadsheet program. When computer makers realized that VisiCalc's practical utility in business applications was a prime reason for individuals to purchase computers, they were eager to bundle the software for sale with their machines. Software Arts used its early positive cash flow to develop good customer relationships, enhance customer service, and build strong relationships with computer manufacturers. Thus, VisiCalc was able to preempt the original equipment manufacturer (OEM) distribution channel by becoming a preferred, manufacturerendorsed software brand. This provided a structural barrier to competitive entry for second mover SuperCalc (introduced nine months later by Sorcim) and third mover Multiplan (introduced 30 months later by Microsoft). Despite having superior products, these follower entries were not successful in breaking VisiCalc's hold on the distribution channel. VisiCalc is an example of a first mover that succeeded in successfully achieving market dominance in a fast-changing product category.

\section{First-Mover Lead Time}

There has been a growing trend for firms to enter markets faster due to shorter product life cycles, faster product obsolescence, and intensified competition (Griffin 1993). Competitors seek to implement organizational and technological strategies that reduce the barriers erected by others, thus decreasing the longer lead times once enjoyed by early movers. Advances in media and communication (Agarwal and Gort 2001), particularly the explosion of growth in technology fueled by computerization and the Internet, has led to quicker dissemination of information, further eroding away the barriers to competitive entry. Both first movers and fast followers have accelerated new product development through a broad variety of strategies, including lead user involvement, training and rewarding employees, increased supplier involvement, speeding activities and tasks, and a simplification of organization structure (Langerak 
and Hultink 2005). Consequently, a number of forces are in play that tend to compress innovation lead times.

Since the late 1980s, there has been a growing recognition that first-moving may no longer be the advantage that it once was, especially if lead times are continuing to decline. Conceptual articles have questioned many of the theoretical advantages assumed to provide long-term advantages to first movers (Lieberman and Montgomery 1998; Mellahi and Johnson 2000). Further, cross-sectional empirical research has indicated that first-mover market share leadership is supported in only 10 percent of major product categories (Golder and Tellis 1993), that being first to market does not necessarily ensure dominant market share or long-term rewards (Chen et al. 2002), and that the initial economic advantage garnered by first movers is significantly reduced following the market entry of second and third movers (Poletti, Engelland, and Ling 2008).

\section{Second-Mover Lead Time}

Game theory has contributed a number of economic models and corresponding research that provides insights into the desirability of various launch order positions $(\mathrm{He}$ et al. 2007). Under conditions of imperfect information, the Stackelberg model predicts that the second mover will be more profitable than the first mover because the second mover will have the chance to observe and learn from the first mover's efforts (Gal-Or 1987). The Stackelberg model presumes that the first mover becomes constrained by initial product configuration and launch decisions made under conditions of imperfect information and is not as nimble in adapting to new market information or optimizing its market offering as the second mover. Consequently, in the real world, a particularly nimble second mover can outmaneuver the first mover and become more successful long term. However, this result is based on a fairly restrictive condition: that the market is a two-brand oligopoly.

When a third entrant is added to the Stackelberg model to create a three-brand oligopoly, the model result is extremely disadvantageous for the second mover. At model equilibrium, the third mover becomes a strategic substitute to the first mover and a strategic complement to the second mover. Under this condition, the second mover earns the lowest expected profit, while the third mover earns the greatest profit (Shinkai 2000). Consequently, this type of economic modeling predicts that the presence of a third mover is a disastrous result for the fast-second launch strategy.

However, Stackelberg economic models do not have the ability to take preference formation effects into consideration. When given enough lead time, earlier market entrants have the advantage of being able to shape consumer preferences (Carpenter and Nakamoto 1989) and establish other structural barriers that make it difficult for later entrants. Given enough lead time, earlier entrants can build brand loyalties that are difficult for later entrants to break away. 
Therefore, an understanding of both market structure and lead time is critical for marketing strategists to make good decisions with respect to launch order. Marketers need to know if it is likely there will be one, two, or three players in any new product category. If a two-brand market is anticipated, what is the likely lead time between first mover launch and second mover response? If a three-brand market is anticipated, what is the likely lead time between first mover and second mover, and what is the likely lead time between second mover and third mover? Are the anticipated lead times sufficient enough to establish preference formation and structural barriers?

A continuation of the previous example may be helpful. In January 1983, 44 months after VisiCalc's launch, Lotus Development Corporation introduced a new innovation called Lotus 1-2-3, the first software that combined three different functions (spreadsheet, graphics, and database management) into one program. This was not a "me-too" introduction, but a significant new-to-the-world product concept. Lotus employed an end-run strategy to break VisiCalc's hold on computer makers: massmarket television advertising directed to consumers. The resulting consumer demand encouraged computer manufacturers to back away from exclusive arrangements with VisiCalc. This strategy caught Software Arts by surprise, and Lotus 1-2-3 quickly surpassed VisiCalc as the preferred consumer choice. In subsequent years, Lotus sealed its strategic victory by acquiring Software Arts and withdrawing VisiCalc from the market, then fending off launches by Mosaic Software (TWIN) and Paperback Software (VP Planner) through successful copyright infringement legal action.

But there is more to the story. Nearly five years later, Microsoft's Multiplan was extended into a spread-sheet-graphics-database product and renamed Excel. This "metoo" product became the fourth mover in this category when it was launched in October 1987 as one of the first applications to take full advantage of the capabilities of Microsoft's new Windows operating system. Despite the fact that Lotus 1-2-3 had established a leading and apparently unassailable market position, and the fact that Excel did essentially the same things as that Lotus 1-2-3, Microsoft used its Windows operating system and a compelling case for multi-application compatibility as wedges to encourage users to acquire a family of Microsoft products. This product family included such programs as Word, PowerPoint, and Excel that eventually became part of Microsoft's Office Suite package. Thus, Excel is a great example of a late mover that successfully overcame the first-mover's structural advantages. As a result, Excel soon nudged out Lotus 1-2-3 as the leading spreadsheet program and has held the number one position since the late 1980s.

\section{The Need for Lead Time Research}

As previously discussed, declining innovation lead time is suspected as the principal cause of the diminution of first-mover advantage, and this supposition provokes additional scrutiny. If lead times are continuing to decline, what is the rate of that 
decline? Is there evidence of a lessening in the rate of decline? A rapid rate of decline would argue that the advantages of being an early mover will become more difficult to establish. With a reduced opportunity to develop the scale economies, technological leadership, brand loyalty, preemptive patenting, and switching cost barriers that preempt competition, the fast follower strategy begins to look much more attractive.

Unfortunately, prior empirical research has concentrated on first-mover lead time and has ignored second-mover lead time. We suggest that this is an important deficiency given that much research has recommended a fast-second strategy with little consideration of the likelihood of a third entrant or the lead time necessary to prevent significant incursion by that entrant. We were unable to find any published research into second-mover lead times. The literature is silent as to whether second-mover lead times are similar in length to first-mover lead times or whether they are declining at a similar rate. Accordingly, a second objective of the present study is to rectify this deficiency by examining second-mover lead times over a 20 -year period.

\section{HYPOTHESES}

The most compelling evidence to date of a constricting innovation lead time is provided by Agarwal and Gort's (2001) study of 46 new product innovations. This research found a decline in lead times from an average of almost 33 years at the end of the nineteenth century to 3.4 years for innovations introduced in the 1980-84 period. The study's empirical evidence suggested that this change resulted largely from a lowering of absolute cost advantages of first movers through easier transfer of knowledge and skills across firms. Further, this change was also facilitated by the growth in markets, rapid information dissemination, reverse engineering, an increase in the population of potential entrants, and greater globalization of markets. The authors concluded that the rate of initial competitive entry has been rapidly and steadily rising over the past century, pointing to an overall weakening of entry barriers and a reduction of first-mover lead times.

A time-series regression analysis revealed a rate of decline of -0.0293 per year. The mean first-mover lead time for the last period of analysis was computed at 3.4 years. However, this decline rate and ending value may both be understated or overstated due to the arbitrary nature of the sample, the relatively small sample size (only 46 data points spread over 100 years), and the retrospective nature of the selection process (inclusion in the sample required that the new product be deemed "significant" according to post hoc analysis rather than perception at time of launch). Another shortcoming is that the source of lead time data was the Thomas Register, a periodical that was published annually during the period of the study. Consequently, dates of new product introduction could only be recorded to the nearest year, and this lack of precision could have some effect on the accuracy of the estimates, particularly in the later periods of the analysis. Clearly, greater examination of innovation lead times is needed.

In order to fulfill the first objective of this research-understanding what is happening to first-mover lead times since Agarwal and Gort's (2001) study ended in 1984-we begin with the null hypothesis expectation that lead times since 1984 are consistent with the 
rate of decrease and an extrapolation of the ending level found by the previous research. Accordingly, we propose that:

Hypothesis 1: The general level of first-mover lead times since 1985 will be consistent with an extension of the trend line found by Agarwal and Gort (2001) in their 100-year study ending in 1984.

Hypothesis 2: The rate of change in first-mover lead times since 1985 will be consistent with the rate of change found by Agarwal and Gort (2001) in their 100-year study ending in 1984.

Another important contribution regarding declining first-mover lead time is borne out in Vakratsas, Rao, and Kalyanaram's (2003) study, which suggested that declines in average lead time were due in large part to the second mover's desire to reduce the increased market-share penalties, which were strongly correlated with longer lead times. In addition, they found that later movers suffer increased market-share penalties, which are different and distinct from those resulting from increased lead time. These findings, coupled with the previously discussed predictions of Stackelberg game theory models, underscore the need to study the lead times of second movers. Consequently, it seems reasonable to assume that third movers, which are already faced with larger market-share penalties than are second movers, would place a strong emphasis on decreasing the lead time between themselves and second movers. Further, third movers benefit from observing the launch of the prior first and second movers and can apply this learning to their own situation to save time in product planning and development activities. All this suggests that second-mover lead times would be shorter than first-mover lead times and that there would be continuing pressure to reduce second-mover lead time further. Accordingly, we propose that:

Hypothesis 3: Mean second-mover lead times since 1985 will be less than mean first-mover lead times during the same period.

Hypothesis 4: Mean second-mover lead times will decline from 1985 forward.

As prior studies have not addressed the rate of change for second-mover lead times, making predictions regarding their rate of change is difficult. However, research referenced earlier (Agarwal and Gort 2001; Langerak and Hultink 2005) suggest that improvements in product development systems are continuing, and presumably are available to all competitors, no matter what launch order. Thus, we would expect to find a consistent rate of lead time reduction, whether first mover or second mover, and we propose:

Hypothesis 5: Second-mover lead times will decline at the same rate as first-mover lead times.

\section{METHODOLOGY}

A study methodology was designed to overcome the previously summarized weaknesses of the Agarwal and Gort (2001) study. Rather than a limited selection of 
innovations based on post hoc performance, a structured content analysis was performed on every new product announcement article appearing in the Wall Street Journal for the 20-year period from January 1, 1985, to December 31, 2004. The Wall Street Journal was employed because it is considered the newspaper of record for financially relevant events (McWilliams and Siegal 1997) and because it satisfied the criteria of consistent dates across announcements, long-term availability, and lack of industry bias. Alternative sources of new product announcements such as the Thomas Register, scientific journals, chronologies, encyclopedias of new product innovations, and trade journals were examined. However, most alternative sources of new product announcements, particularly trade publications, are weekly, bimonthly, or monthly, leading to obvious problems in the accurate determination of the actual announcement dates.

The content of each new product announcement was analyzed by a team of three researchers for key words to determine if the product was classifiable as truly "new to the world" or rather simply a "new and improved" modification of previously available products. The "not representative" rule (Bearden, Netemeyer, and Teel 1989; Netemeyer, Boles, and McMurrian 1996; Netemeyer, Burton, and Lichtenstein 1995) was observed wherein products not classified as new to the world by the entire team were eliminated from consideration. For each new product identified, a rigorous effort was conducted to find second- and third-mover entries using a wide variety of sources. Nevertheless, due to the fact that new product announcements of second- and thirdmarket entrants were not considered newsworthy enough in all cases to warrant inclusion in the Wall Street Journal, alternative sources of new product announcements, including the New York Times, LexisNexis databases, and trade journals, were also consulted to find and verify the new product announcement activities of both secondand third-market entrants. Previously anticipated new products were omitted from the analysis because it was difficult to determine the precise date when the details of the new product became available to consumers and the industry. Consequently, the pharmaceutical industry was eliminated because of prior clinical trial publicity, and the automobile industry was eliminated because of the prevalence of preannouncement publicity.

The product with the first announcement of a product that was the same or imitative of one of the new-to-the world products was considered the second mover, and the date of this announcement was recorded. Similarly, the next competitor to announce a competing product was considered the third mover. No efforts were made to identify fourth or later movers. The number of days between each new product announcement and subsequent rival entry was then entered into an Excel spreadsheet and averaged across all firms and industries. This search and classification procedure yielded a total sample comprising 630 first movers, 423 second movers, and 158 third movers across 24 different industries during the 20-year span of analysis (see Table 1 for an industry analysis). 


\section{Table 1}

Number of First-Mover/Second-Mover Pairs by Three-Digit SIC Code

\begin{tabular}{|c|c|c|}
\hline $\begin{array}{l}\text { SIC } \\
\text { Code } \\
\end{array}$ & Product Description & umber \\
\hline 200 & Food and Kindred Products & 42 \\
\hline 202 & Dairy Products & 36 \\
\hline 203 & Canned, Frozen, and Preserved Fruits, Vegetables, and Food Specialties & 27 \\
\hline 204 & Grain Mill Products & 4 \\
\hline 208 & Beverages & 29 \\
\hline 210 & Tobacco Products & 13 \\
\hline 230 & Apparel and Other Finished Products of Fabrics and Similar Material & 9 \\
\hline 280 & Chemicals and Allied Products & 22 \\
\hline 282 & Plastic Material, Synthetic Resin/Rubber, Cellulose & 31 \\
\hline 284 & Soap, Detergents, Cleaning Preparations, Perfumes, Cosmetics & 57 \\
\hline 287 & Agricultural Chemicals & 7 \\
\hline 352 & Farm Machinery and Equipment & 11 \\
\hline 354 & Metalworking Machinery and Equipment & 5 \\
\hline 357 & Computer and Office Equipment & 45 \\
\hline 360 & Electronic and Other Electrical Equipment & 23 \\
\hline 363 & Household Appliances & 18 \\
\hline 364 & Electrical Lighting and Wiring Equipment & 3 \\
\hline 367 & Electronic Components and Accessories & 13 \\
\hline 369 & Miscellaneous Electrical Machinery, Equipment, and Supplies & 9 \\
\hline 372 & Aircraft and Parts & 5 \\
\hline 376 & Guided Missiles and Space Vehicles and Parts & 4 \\
\hline 391 & Jewelry, Silverware, and Plated Ware & 3 \\
\hline 395 & Pens, Pencils, and Artists' Materials & 4 \\
\hline \multirow[t]{2}{*}{396} & Costume Jewelry and Novelties & 3 \\
\hline & Total & 423 \\
\hline
\end{tabular}




\section{FINDINGS}

Of the 630 new-to-the-world innovations retained for analysis, 423 (67 percent) attracted at least one imitator and 158 (25 percent) attracted at least two. First-mover lead times were computed by determining the number of days between the first-mover announcement and the second-mover announcement. Second-mover lead times were determined by computing the number of days between the second- and third-mover announcements.

First-mover lead times in our sample ranged from a low of 91 days ( 0.25 years) to a high of 625 days ( 1.71 years), with a mean of 321 days ( 0.88 years) over the 20 -year time frame (Figure 1). Annual ranges in lead time values averaged 335 days $(0.92$ years) from low to high each year. However, there was a clear downward trend in mean first-mover lead times. Annual means from 1993 forward were all less than 365 days. By 2004, mean first-mover lead time was 171 days ( 0.47 years).

The first hypothesis dealt with a comparison of the general level of first-mover lead times. To test this hypothesis, we chose to compare the mean first-mover lead time at the end point of the Agarwal and Gort (2001) study with the beginning point for our study. By implementing our methodology, we found 48 new product innovations in 1985 and 1986. Lead times ranged from 197 days ( 0.54 years) to 603 days (1.65 years), with a mean of 382 days ( 1.05 years). This mean is significantly less than the 3.4 years estimated by Agarwal and Gort (2001), based on the last five new product innovations they included in their study. Accordingly, Hypothesis 1 is rejected.

The second hypothesis dealt with the rate of change in first-mover lead time from 1985 through 2004. Based on a time-series regression of nonweighted mean lead times, we found that the 90 percent confidence interval for the first-mover rate of change was $0.0310 \pm 0.004$ (Table 2) versus the -0.0293 found by Agarwal and Gort (2001). There is no significant difference between these two values, and accordingly, Hypothesis 2 is supported.

The number of first-mover/second-mover pairs is presented in Table 2 by study year, along with the highest, lowest, and mean first-mover lead time values. Second-mover lead times in our sample ranged from a low of 26 days ( 0.07 years) to a high of 442 days ( 1.21 years), with a mean of 115 days ( 0.32 years) over the 20 -year time frame (Figure 2).

The third hypothesis dealt with the relationship between first-mover and second-mover lead times, and our results indicate a statistically significant difference. At 115 days (0.31 years), mean second-mover lead times were clearly less than the 321-day mean ( 0.88 years) found for first movers, and, accordingly, Hypothesis 3 was supported.

The fourth hypothesis dealt with whether second-mover lead time is declining, and our results indicate a slight but statistically significant rate of decline. Accordingly, Hypothesis 4 is supported.

The fifth hypothesis dealt with whether first-mover and second-mover lead times are declining at the same rate during the study period. Our results found a statistically 
significant difference. Accordingly, Hypothesis 5 is not supported. First-mover lead time is declining at six times the rate of second-mover lead time decline.

In order to determine whether the changes we observed in lead times over the 20-year study period might have anything to do with unintended changes in the mix of productindustries represented in the sample, a chi-square goodness-of-fit test for frequencies was conducted (Churchill, Brown, and Suter 2010). The sample data were divided into thirds so that the first third represented products introduced early in the 20-year study period, the second third represented products introduced in the middle years, and the last third represented products introduced in the last years of the study. A frequency distribution was compiled for each third and that distribution was compared to the overall 20-year distribution. Computed chi-square values were 5.63 for the first-third data, 9.99 for the second-third data, and 11.12 for the last-third data, all less than the 13.09 test statistic for 23 degrees of freedom and a 0.05 level of significance.

Consequently, we cannot reject the null hypothesis, and we conclude that the productindustry distributions are statistically the same throughout the study.

Figure 1

Highest, Lowest, and Mean First-Mover Lead Times by Year

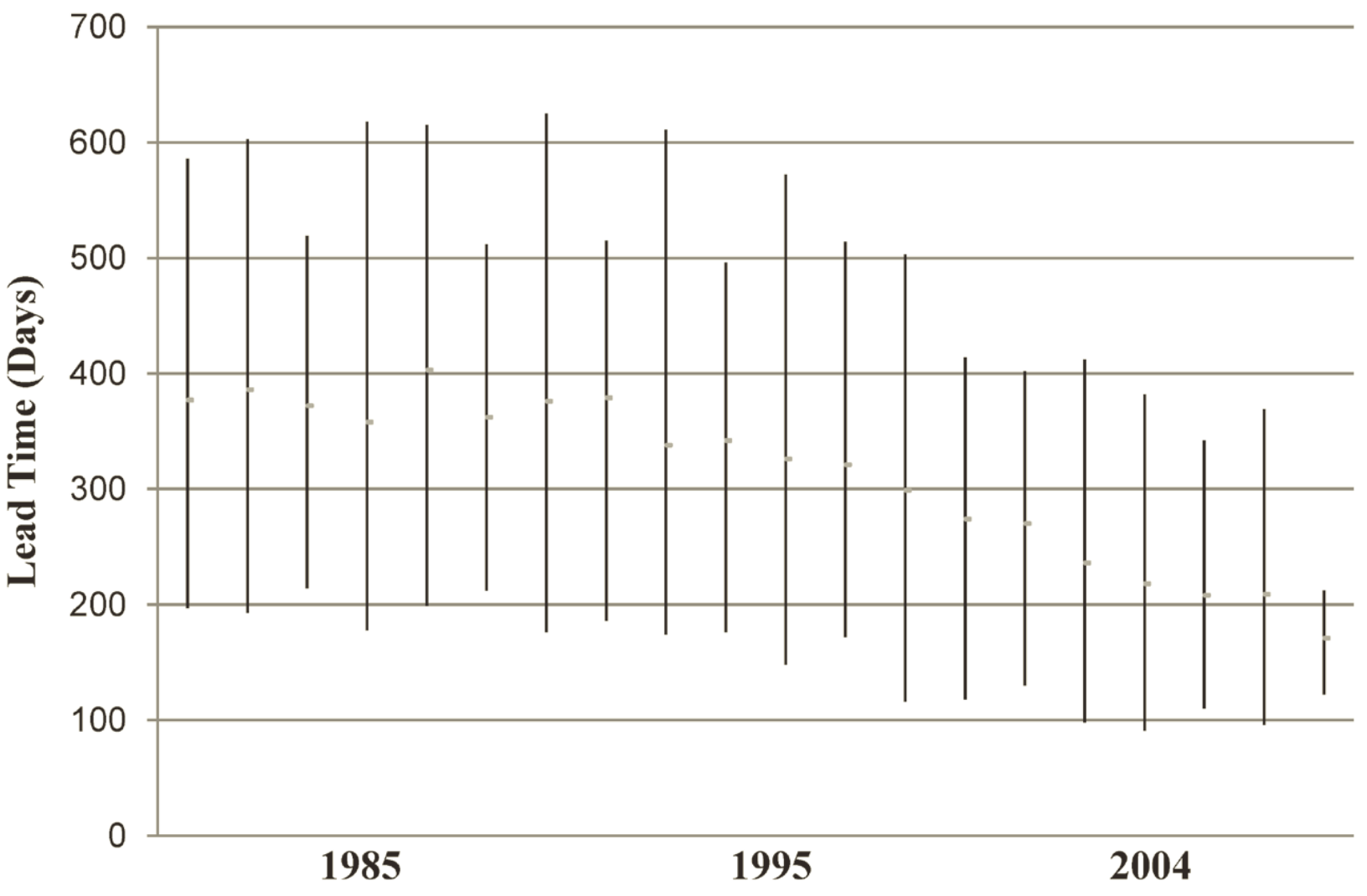


Table 2

Innovation Lead Time Rates of Decline

First-Mover Lead Time

\begin{tabular}{|c|c|c|c|c|}
\hline \multirow[b]{2}{*}{ Variable } & & \\
\hline & Estimate & $t(p$-value $)$ & Estimate & $t$ (p-value) \\
\hline Intercept & 1.18 years & $\begin{array}{l}37.83 \\
(0.001)\end{array}$ & 0.362 years & $\begin{array}{l}14.904 \\
(0.001)\end{array}$ \\
\hline $\begin{array}{l}\text { Year of Product } \\
\text { Announcement }\end{array}$ & -0.031 & $\begin{array}{l}-11.92 \\
(0.001)\end{array}$ & -0.005 & $\begin{array}{l}-2.24 \\
(0.038)\end{array}$ \\
\hline
\end{tabular}

Figure 2

Highest, Lowest, and Mean Second-Mover Lead Times by Year

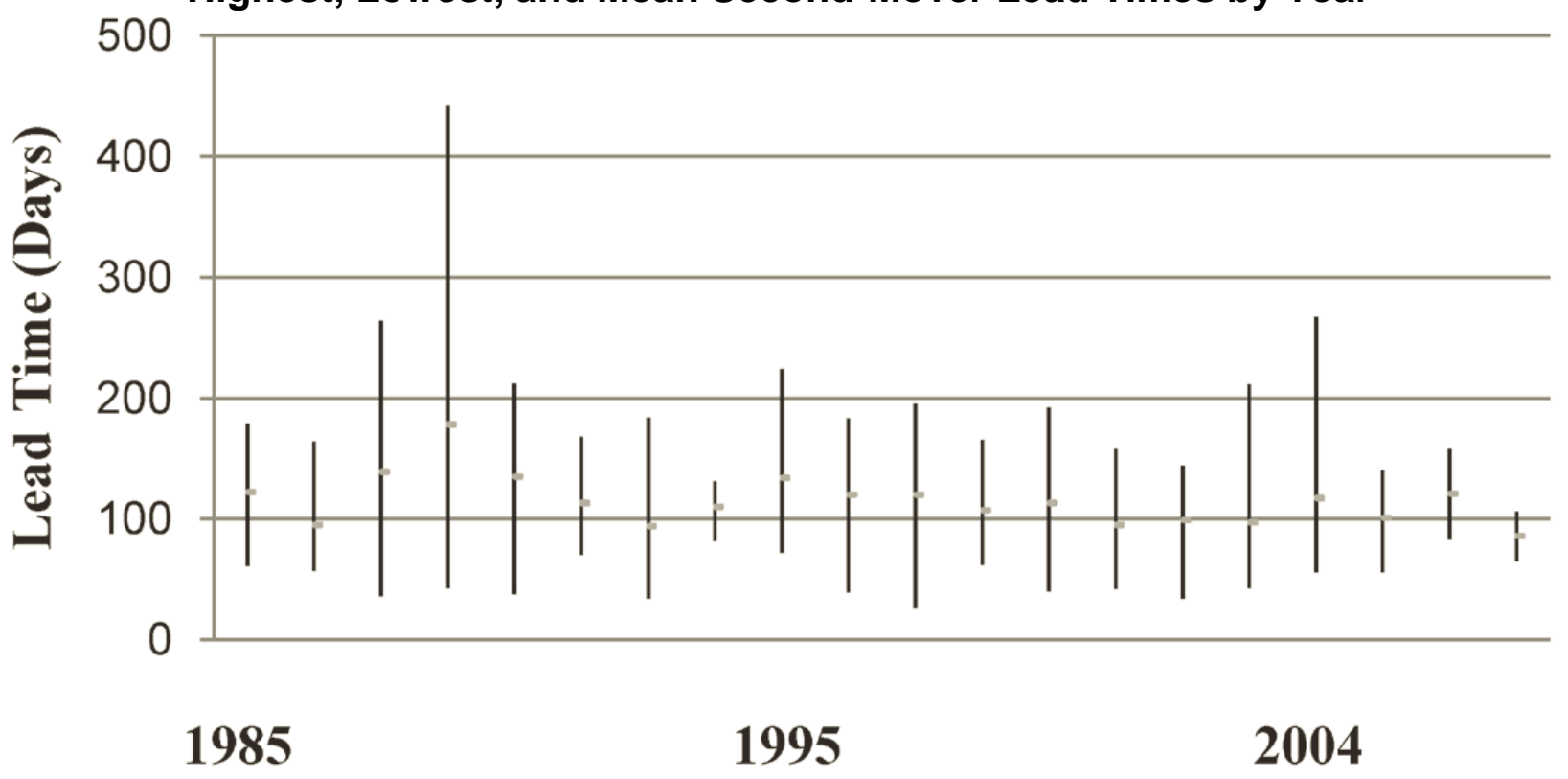




\section{DISCUSSION AND CONCLUSIONS}

It has been well documented that securing adequate lead time is a major factor in determining the rewards garnered by new product innovation. From a strategic standpoint, first movers are motivated to not only be first to market but also to build high enough barriers to competitive entry so as to delay second movers or deter them from market entry. Second movers are motivated to develop product offerings that capture the opportunity left to them while making it difficult or undesirable for third movers to enter and upset the established market dynamics. In our study, 33 percent of first movers never experienced the disrupting presence of a second mover throughout the study period, and 62 percent of second movers never experienced the disrupting presence of a third mover. This underscores the fact that not all new product innovations attract competitive entry. When marketing executives plan launch order strategy, they must anticipate the likelihood of competitive entries in addition to realistic lead time expectation.

This study has been successful in extending prior research by confirming that firstmover lead time has continued to decline at a significant rate through 2004. The rate of change that we observed is -0.031 per year, which is within the statistical range of the findings of Agarwal and Gort (2001). However, our study found a much shorter firstmover lead time than did Agarwal and Gort relative to the final years of their analysis, 377 days ( 1.03 years) in our study versus 1,241 days (3.4 years) in theirs. Reasons for the difference may be an artifact of the differences in the sample selection process. Agarwal and Gort limited their sample to selected innovations that they deemed historically significant and, as a result, may have biased their results by failing to include a broad enough range of innovations. For instance, Agarwal and Gort included pharmaceutical products protected by patents while ignoring the food product category, the beverage category, and household cleaning products category, all products with potentially shorter product-development cycles.

Our findings indicate that average first-mover lead time declined by 55 percent from 377 days ( 1.03 years) in 1985 to 171 days ( 0.47 years) in 2004 . There appeared to be no evidence of a slowing in the rate of decline.

This study was also successful in measuring second-mover lead times for a broad sample of products. Our results demonstrate that second-mover lead times are significantly shorter than first-mover lead times, but at the same time, the likelihood of further competitive entry is much lower than for first movers. This would suggest that fast followers experience much less risk of changes in market composition and dynamics than first movers do and provides a key advantage for second movers that is not identified in the current literature. Indeed, the fast-follower approach could be increasingly viable as lead times continue to decrease.

Finally, this study found a materially small but statistically significant decline in secondmover lead time. Mean lead time decreased from 108 days ( 0.295 years) in the first two years studied, to 103 days (0.282 years) in the last two years studied, a 4.6 percent decline. This average rate of decline over the 20 -year period was much lower than the decline rate for first movers, and a visual analysis of the data suggests a flattening of 
the curve since 1995. This suggests that reductions in second-mover lead times may have reached a point of diminishing returns.

Second-mover lead times have decreased at a slower rate than first-mover lead times for two possible reasons. First, profit-making firms may perceive a large difference in the potential payoff from being second versus third in the race to market new products and order their launch efforts accordingly. Once the race is lost for second place, firms may place their resources not on getting to the market faster but, rather, on getting to the market better by making certain that their product and strategy are correct given the changing competitive situation. This might require extra time and study in understanding how consumer segments are reacting to the first and second mover's offerings so that niche opportunities may be uncovered. Second, there may be essential differences in firms with a first-mover culture versus firms with a third-mover culture. Those firms that aim for first entry, even though they occasionally come in second, have a different strategic intent from that of firms that aim for third. They expend resources on speeding up their decision processes so that they can increase their first-to-market winning percentage. But not every competitor is playing this game. Some firms may be perfectly content with a low-risk strategy of producing low-differentiated products at low cost, and these may be the firms that we observed as third movers.

\section{LIMITATIONS AND FUTURE RESEARCH}

This work has two limitations that need to be acknowledged, both of which could potentially affect the results. The first relates to our use of the Wall Street Journal as the key source of first-mover identification. As mentioned earlier, the Wall Street Journal enabled us to capture lead times to the nearest day, but no source is without problems. The choice of Wall Street Journal naturally tends to eliminate product innovations introduced by small, privately funded companies that are not motivated to announce their new-to-the-world innovation to national financial markets in order to attract investment capital or raise the price of their stock. Undoubtedly, this source also tended to underrepresent innovations launched by local or regional companies.

The second limitation is that. although innovation lead times are likely to be different for different types of products or different industries, our study did not attempt to select an equal number of first movers for every type or industry. New products that require significant developmental research, high levels of new capital equipment for production, or extended periods of prelaunch certification testing can be expected to have longer lead times. In fact, pharmaceutical and automotive products were specifically eliminated because of our concern that true innovation lead time was masked by extended prelaunch trials and preannouncement publicity in these industries. Because innovation lead times may tend to be longer for such products, our omission of them might have understated the overall average lead estimates reported in our analysis. But differences between industry segments are not clear, and we were unable to locate prior empirical research that assessed lead times for different product categories or different industry groups. Consequently, additional research should be conducted to examine lead time differences for different product, firm, or industry classifications. 
Recent work integrating first-mover advantage with the resource-based view (RBV) of the firm (Finney, Lueg, and Campbell 2008; Morgan 2000; Morgan and Hunt 1999) may be very beneficial in this regard. The RBV suggests that there is a difference between the management skills of first movers and the management skills of late movers. Firstmover skills are posited to include (1) efficient acquisition, (2) bundling/combining, (3) positioning, and (4) maintenance/protection skills. Late movers, however, may need a different set of skills that enable them to benchmark the initiatives of the first movers, creatively copy and improve these initiatives, and then introduce competitive entries that some market segments find attractive. This idea that early movers have different skill sets than followers needs to be empirically validated. Technological developments (data storage and retrieval, communications technology, etc.) support improvements in the resource management skills required by early movers, but these technological developments appear to have had a much less dramatic effect on the speed of reaction for the late-mover skills of benchmarking and copying. These differences should be evaluated.

Our study suggests that if first movers are to be successful under conditions of rapidly declining lead times, they have a smaller and smaller window of opportunity to establish their market competitive advantage. Research needs to be conducted that uncovers the salient keys to success for the first mover, and to what extent those keys include greater marketing competence, sophistication, speed, and dexterity on the part of the first mover. Conversely, further empirical research is appropriate to evaluate followers' use of benchmarking, market segmentation, and increasing promotional expenditures to achieve higher consumer relative preferences in targeted segments. Ideally, followers should make efforts to decrease lead times while simultaneously increasing consumer preference formation, if firm resources allow such strategies to be pursued and executed effectively.

Research should also be directed toward understanding the role of intangible, organizational, and relational resources in determining launch order success. Intangible skills may be contributing differently to first-mover success (Barnes, Collier, and Lueg 2009). These intangible skills include embedding operant resources through programs that train employees in areas such as understanding the consumer's perspective, empower employees to react to the dynamic relationship with the customer, and monopolize the control over scarce resources within the environment, including both physical and nonphysical types (Barnes, Collier, and Lueg 2009).

Finally, additional research is needed to more fully understand (1) the reasons for the rate of decline differences between first-mover and second-mover lead times we have documented, (2) the potential for further reductions in innovation lead time, and (3) the influence of strategic posture related to efforts to speed market entry. Of particular interest is the relationship between first-mover strategic investments in areas such as research and development or advertising, and the ultimate lead time attainment by those firms. 


\section{REFERENCES}

Agarwal, Rajshree, and Michael Gort (2001), "First-Mover Advantage and the Speed of Competitive Entry, 1887-1986," Journal of Law and Economics, 44 (1), 161-177.

Alpert, Frank H. (1987), "Product Categories, Product Hierarchy, and Pioneership: A Framework," in AMA Educators' Proceedings, Michael R. Solomon and Susan P. Douglas, eds., Chicago: American Marketing Association, 133-138.

Barnes, Donald C., Joel E. Collier, and Jason Lueg (2009), "Reevaluating the Theoretical Reasoning Regarding, Market-Entry Position from a Service-Dominant Logic Perspective," Journal of Marketing Theory and Practice, 17, 2 (Spring), 163-174.

Bearden, William O., Richard G. Netemeyer, and Jesse E. Teel (1989), "Measurement of Consumer Susceptibility to Interpersonal Influence," Journal of Consumer Research, 15 (March), 473-481.

Buzzell, Robert D., Bradley T. Gale, and Ralph G.M. Sultan (1975), "Market Share-A Key to Profitability," Harvard Business Review, 53 (1), 97-106.

Carpenter, Gregory S., and Kent Nakamoto (1989), "Consumer Preference Formation and Pioneering Advantage," Journal of Marketing Research, 26 (August), 285298.

— Dominant Brand," Management Science, 36 (10), 1268-1278.

Chen, Sheng-Syan, Kim Wai Ho, Kueh Hwa Ik, and Cheng-Few Lee (2002), "How Does Strategic Competition Affect Firm Values? A Study of New Product Announcements," Financial Management, 21 (2), 67-84.

Churchill, Gilbert A., Jr., Tom J. Brown, and Tracy A. Suter (2010), Basic Marketing Research, 7th ed., Mason, OH: South-Western Cengage Learning.

Conrad, Cecilia (1983), "The Advantage of Being First and Competition Between Firms," International Journal of Industrial Organization, 1 (4), 353-364.

D’Aveni, Richard A. (1994), Hypercompetition: Managing the Dynamics of Strategic Maneuvering, New York: Free Press.

Engelland, Brian T., and Bruce L. Alford (2000), "Consumer Learning and the Creation of Primacy Advantages for Followers," Journal of Business Strategies, 17 (2), 145-162.

Finney, R. Zachary, Jason E. Lueg, and Noel D. Campbell (2008), "Market Pioneers, Late Movers, and the Resource-Based View (RBV): A Conceptual Model," Journal of Business Research, 61 (September), 925-932.

Gal-Or, Esther (1987), "First-Mover Disadvantages with Private Information," Review of Economic Studies, 54 (2), 279-292. 
Golder, Peter N., and Gerard J. Tellis (1993), "Pioneer Advantage: Marketing Logic or Marketing Legend?" Journal of Marketing Research, 30 (2), 158-170.

Griffin, Abbie (1993), "Metrics for Measuring Product Development Cycle Time," Journal of Product Innovation Management, 10 (2), 112-125.

He, Xiuli, Ashutosh Prasad, Suresh Sethi, and Genaro Gutierrez (2007), "A Survey of Stackelberg Differential Game Models in Supply and Marketing Channels," Journal of Systems Science and Systems Engineering, 16 (4), 385-413.

Huff, Lenard C., and William T. Robinson (1994), "Note: The Impact of Lead Time and Years of Competitive Rivalry on Pioneer Market Share Advantages," Management Science, 40 (10), 1370-1377.

Kahn, Kenneth B. (2004), "Accelerated Product Development: Techniques and Traps," in The PDMA Handbook of New Product Development, $2 \mathrm{~d}$ ed., Kenneth B. Kahn, ed., New York: John Wiley \& Sons, 173-187.

Kalyanaram, Gurumurthy, William T. Robinson, and Glen L. Urban (1995), "Order of Market Entry: Established Empirical Generalizations, Emerging Empirical Generalizations, and Future Research," Marketing Science, 14, 3 (Supplement), G212-G221.

Kuester, Sabine, Christian Homburg, and Thomas S. Robertson (1999), "Retaliatory Behavior to New Product Entry," Journal of Marketing, 63 (4), 90-106.

Langerak, Fred, and Erik Jan Hultink (2005), "The Impact of New Product Development Acceleration Approaches on Speed and Profitability: Lessons for Pioneers and Fast Followers," IEEE Transactions on Engineering Management, 52 (1), 30-42.

Lee, Hun, Ken G. Smith, Curtis M. Grimm, and August Schomberg (2000), "Timing, Order and Durability of New Product Advantages with Imitation," Strategic Management Journal, 21 (1), 23-30.

Lieberman, Marvin B., and David B. Montgomery (1988), "First-Mover Advantages," Strategic Management Journal, 9 (Summer), 41-58.

— , and - (1998), "First-Mover (Dis)Advantages: Retrospective and Link with the Resource-Based View," Strategic Management Journal, 19 (2), 1111-1125.

McWilliams, Abagail, and Donald Siegal (1997), "Event Studies in Management Research: Theoretical and Empirical Issues," Academy of Management Journal, 40 (3), 626-657.

Mellahi, Kamel, and Michael Johnson (2000), "Does It Pay to Be a First-Mover in e.Commerce? The Case of Amazon.com," Management Decision, 38 (7), 445454.

Morgan, Robert M. (2000), "Relationship Marketing and Marketing Strategy: Evolution of Relationship Strategy Within the Organization," in Handbook of Relationship Marketing, Jagdish Sheth and Atul Parvatiyar, eds., Thousand Oaks, CA: Sage, 481-504. 
_ and Shelby Hunt (1999), "Relationship-Based Competitive Advantage: The Role of Relationship Marketing in Marketing Strategy," Journal of Business Research, 46 (November), 281-290.

Nelson, Richard R., and Stanley G. Winter (1982), An Evolutionary Theory of Economic Change, Cambridge, MA: Belknap Press.

Netemeyer, Richard G., James S. Boles, and Robert McMurrian (1996), "Development and Validation of Work-Family Conflict and Family-Work Conflict Scales," Journal of Applied Psychology, 81 (4), 400-410.

— Scot Burton, and Donald R. Lichtenstein (1995), "Trait Aspects of Vanity: Measurement and Relevance to Consumer Behavior," Journal of Consumer Research, 21 (March), 612-626.

Patterson, William C. (1993), "First-Mover Advantage: The Opportunity Curve," Journal of Management Studies, 30 (September), 759-777.

Poletti, Michael, Brian Engelland, and Howard Ling (2008), "An Empirical Study of Launch Order Valuation Based Upon Stock Market Reaction," Marketing Management Journal, 18 (1), 1-13.

Robinson, William T. (1988), "Sources of Market Pioneer Advantages: The Case of Industrial Goods Industries," Journal of Marketing Research, 25 (1), 87-94.

_ Evidence for Industrial Goods Businesses," Journal of Marketing Research, 39 (1), 120-128.

Schmalensee, Richard (1982), "Product Differentiation Advantages of Pioneering Brands," American Economic Review, 72 (3), 349-365.

Shinkai, Tetsuya (2000), "Second Mover Disadvantages in a Three- Player Stackelberg Game with Private Information," Journal of Economic Theory, 90 (2), 293-304.

Short, Jeremy C., and G. Tyge Payne (2008), "First-Movers and Performance: Timing Is Everything," Academy of Management Review, 33 (1), 267-270.

Suarez, Fernando F., and Gianvito Lanzolla (2005), "The Role of Environmental Dynamics in Building a First-Mover Advantage Theory," Academy of Management Review, 32 (2), 377-392.

— and - (2007), "The Half-Truth of First-Mover Advantage," Harvard Business Review, 83 (April), 121-127.

— , and - (2008), "Considerations for a Stronger First-Mover Advantage Theory," Academy of Management Review, 33 (1), 269-270.

Vakratsas, Demetrios, Ram C. Rao, and Gurumurthy Kalyanaram (2003), "An Empirical Analysis of Follower Entry Timing Decisions," Marketing Letters, 14 (3), 203-216.

Von Hippel, Eric (1984), The Sources of Imitation, New York: Oxford University Press. 
"This is an Accepted Manuscript of an article published by Taylor \& Francis in the Journal of Marketing Theory \& Practice (Winter 2011, Vol. 19 Issue 1), available online:

http://wwww.tandfonline.com/ [Article DOI:10.2753/MTP1069-6679190102." 